\title{
ELEANOR MILNE
}

\section{FISHING FOR ANSWERS: THE IMPLICATIONS OF ENVIRONMENTAL DEFENCE SOCIETY V KING SALMON}

Submitted for the LLB (Honours) Degree

Faculty of Law

Victoria University of Wellington 


\section{Abstract}

The Supreme Court's decision Environmental Defence Society v King Salmon, released in early 2014, is a positive development in New Zealand's resource management law. The decision endorses the environmental bottom line approach and prohibits the use of the purpose section of the Resource Management Act 1991 when making operative decisions. If the decision is applied widely, there is scope for some of the problems with the resource management law framework to be addressed. In particular, it has the potential to reduce the uncertainty within the system caused by the lack of central government direction and the inconsistencies between local governments, and the issues when applying the purpose of the Resource Management Act. The paper also analyses the effect of King Salmon on the proposed reforms, and concludes that the arguments for the reforms are now much weaker. 
TABLE OF CONTENTS

II INTRODUCTION ...............................................................................................................................4

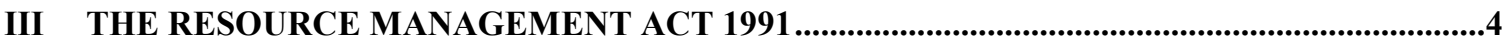

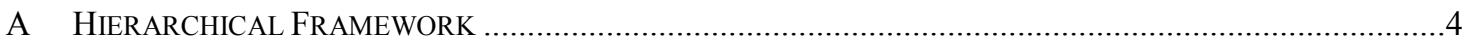

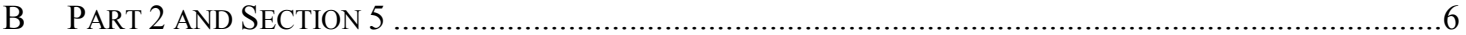

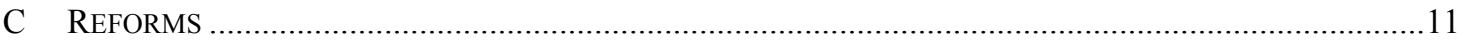

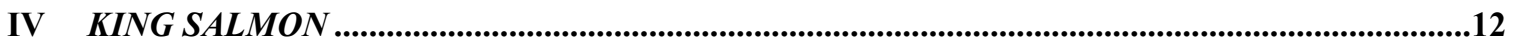

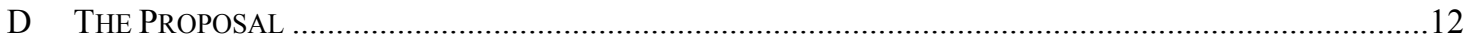

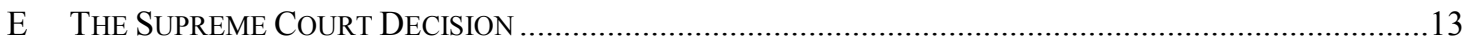

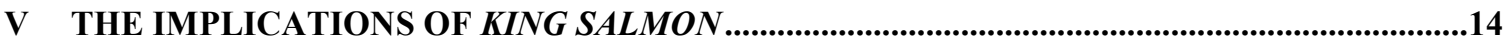

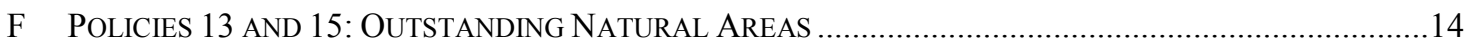

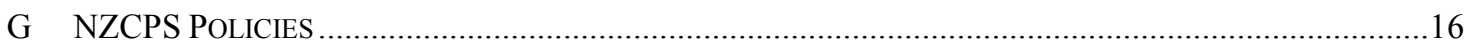

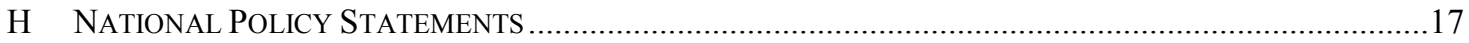

1 Was the planning document intended to be capable of containing environmental bottom lines? 17

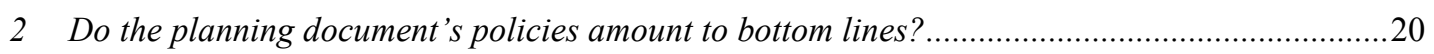

3 Is the decision-maker entitled to refer back to the purpose of the RMA?......................................21

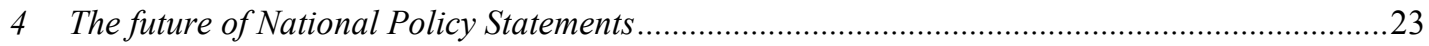

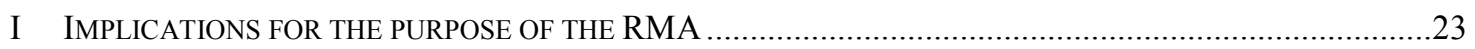

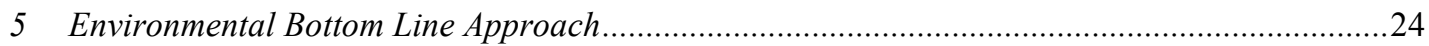

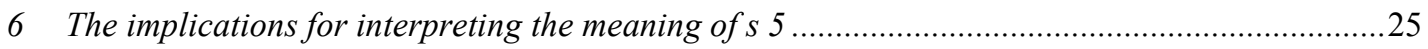

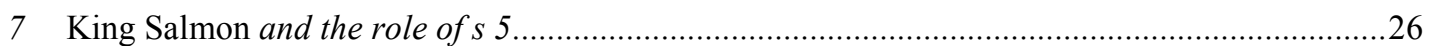

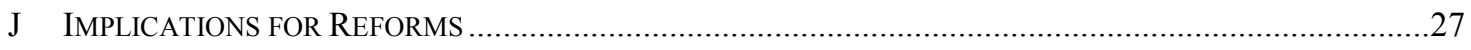

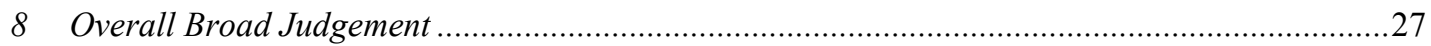

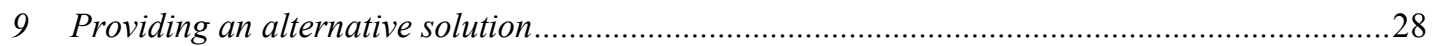

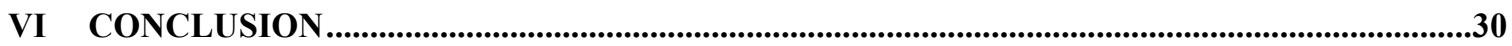

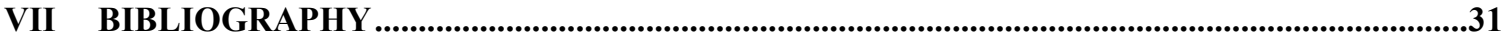




\section{Introduction}

New Zealand's resource management law regulates our relationship with the natural environment. It thereby affects people and how they live their lives, and has a significant influence on local authorities. Because of this, national consistency and certainty are important principles for resource management law, to ensure that decisions are fair and that local administration functions efficiently. Unfortunately, in this respect, the framework established by the Resource Management Act 1991 (RMA) has room for improvement.

In April this year, the Supreme Court released the Environmental Defence Society $v$ New Zealand King Salmon Co Ltd (King Salmon) decision, which rejected an application by the New Zealand King Salmon Co Ltd (King Salmon) for a salmon farm in the Marlborough Sounds. ${ }^{1}$ The decision has been said to have caused a "seismic shift" in resource management law. ${ }^{2}$

This paper will outline the relevant elements of the state of New Zealand's resource management law, briefly explain the King Salmon decision, then analyse the possible effects the case will have on the various layers of the Resource Management Act 1991 hierarchy. It will focus on the elements of the decision that address the "environmental bottom line approach", and conclude that the results in King Salmon have the potential to improve the RMA framework and address some of the persistent problems.

\section{The Resource Management Act 1991}

\section{A Hierarchical Framework}

A fundamental element of the RMA framework is its hierarchy of planning documents. There are several levels of instruments, and they tend to move from the general to the

\footnotetext{
${ }^{1}$ Environmental Defence Society Inc v New Zealand King Salmon Co Ltd [2014] NZSC 38 [King Salmon (SC)].

${ }^{2}$ Gary Taylor, Chairman of Environmental Defence Society "Introduction" (speech to seminar on EDS v King Salmon, Auckland, 4 June 2014).
} 
specific, both in substance and location. ${ }^{3}$ The Act itself sits atop the framework, with Part 2 and s 5 at its core. The next instruments in the hierarchy are national and coastal policy statements, issued by central government and applying nationally. Under these are regional policy statements and regional and district plans, developed by local authorities. Generally the lower documents in the hierarchy are bound by those above them. ${ }^{4}$ A Regional Plan, for example, must "give effect" to the New Zealand Coastal Policy Statement (NZCPS). ${ }^{5}$ Thus the higher level policy instruments are a way for central government to provide direction to local authorities, retaining some control over the framework and enabling consistency and coherency. ${ }^{6}$

The RMA was an ambitious legislative development, but it fell short of its high expectations because of a rather lacklustre implementation. ${ }^{7}$ Central government did not commit to its role in the hierarchy, neglecting to establish national instruments. The first policy statement issued was the NZCPS, adopted in 1994, in compliance with the RMA's requirement that there be an NZCPS at all times. ${ }^{8}$ It was fourteen years before the next NPS was released: the National Policy Statement on Electricity Transmission (NPSET) in 2008. ${ }^{9}$ Following this, in 2011 the National Policy Statements on Freshwater Management (NPSFM) and the National Policy Statement for Renewable Energy Generation (NPSREG) were released. ${ }^{10}$ A National Policy Statement on Indigenous Biodiversity is in

\footnotetext{
${ }^{3}$ King Salmon (SC), above n 1, at [14].

${ }^{4}$ Rob Harris (ed) Handbook of Environmental Law (Royal Forest and Bird Protection Society, Wellington, 2004) at 60.

${ }^{5}$ Resource Management Act 1991, s 67(3).

${ }^{6}$ Derek Nolan (ed) Environmental and Resource Management Law (LexisNexis, online looseleaf ed) at [3.76].

7 Bret Birdsong Adjudicating Sustainability: New Zealand's Environment Court and the Resource Management Act (Ian Axford Fellowship in Public Policy, 2008) at 1.

${ }^{8}$ Department of Conservation New Zealand Coastal Policy Statement 2010 (issued by notice in the New Zealand Gazette on 4 November 2010 and taking effect on 3 December 2010) and Resource Management Act 1991, s 57(1).

${ }^{9}$ Ministry for the Environment National Policy Statement on Electricity Transmission (issued by notice in the New Zealand Gazette on 13 March 2008).

${ }^{10}$ Ministry for the Environment National Policy Statement on Freshwater Management 2011 (issued by notice in the New Zealand Gazette on 12 May 2011) and Ministry for the Environment National Policy
} 
development, the implementation of which would bring the total number of national instruments to five. ${ }^{11}$ The shortage of NPSs has left local authorities to implement the RMA largely unconstrained and undirected. ${ }^{12}$ Local governments' decisions were made more difficult and time-consuming, and inconsistencies between regions plagued the framework. ${ }^{13}$ There have been many calls for central government to provide more direction. $^{14}$

\section{B Part 2 and Section 5}

Part 2 is the "engine room" of the RMA. ${ }^{15}$ It contains governing principles that are referred to throughout the framework, ${ }^{16}$ and underlies almost every discretion exercised under the RMA. ${ }^{17}$ Of particular importance is section 5, a broad, principled provision that defines the purpose of the RMA:

(1) The purpose of this Act is to promote the sustainable management of natural and physical resources.

(2) In this Act, sustainable management means managing the use, development, and protection of natural and physical resources in a way, or at a rate, which enables people and communities to provide for their social, economic, and cultural well-being and for their health and safety while-

Statement for Renewable Energy Generation 2011 (issued by notice in the New Zealand Gazette on 14 April 2011).

${ }^{11}$ Ministry for the Environment Proposed National Policy Statement on Indigenous Biodiversity (January 2011).

12 Royden Somerville The Resource Management Act 1991: An Introductory Review (Thomson Reuters, online ed, 2004) at [IN5.04].

${ }^{13}$ Neil J Ericksen and others Planning for Sustainability: New Zealand Under the RMA (The International Global Change Institute, Hamilton, 2003) at 287.

14 Ministry for the Environment Improving our resource management system: $A$ discussion document (ME1103, 2013) at 20-21 and Ministry for the Environment Summary of submissions: improving our resource Management system at 11.

${ }^{15}$ Auckland City Council v John Woolley Trust [2008] NZRMA 260 (HC) at [47].

${ }^{16}$ Derek Nolan, above n 6, at [3.15].

${ }^{17}$ Royden Somerville, above n 12, at [IN4.02] - [IN4.03]. 
(a) sustaining the potential of natural and physical resources (excluding minerals) to meet the reasonably foreseeable needs of future generations; and

(b) safeguarding the life-supporting capacity of air, water, soil, and ecosystems; and

(c) avoiding, remedying, or mitigating any adverse effects of activities on the environment.

The rest of Part 2 consists of ss 6, 7 and 8, which elaborate on the definition of sustainable management and provide more specific direction. ${ }^{18}$

\section{Matters of national importance}

In achieving the purpose of this Act, all persons exercising functions and powers under it, in relation to managing the use, development, and protection of natural and physical resources, shall recognise and provide for the following matters of national importance:

(a) the preservation of the natural character of the coastal environment (including the coastal marine area), wetlands, and lakes and rivers and their margins, and the protection of them from inappropriate subdivision, use, and development:

(b) the protection of outstanding natural features and landscapes from inappropriate subdivision, use, and development:

(c) the protection of areas of significant indigenous vegetation and significant habitats of indigenous fauna:

(d) the maintenance and enhancement of public access to and along the coastal marine area, lakes, and rivers:

(e) the relationship of Maori and their culture and traditions with their ancestral lands, water, sites, waahi tapu, and other taonga:

(f) the protection of historic heritage from inappropriate subdivision, use, and development:

\footnotetext{
${ }_{18}$ Peter Salmon Environmental Law- Resource Management Act 1991 (Thomson Reuters, online looseleaf ed) at [RMPt2.01].
} 
(g) the protection of protected customary rights.

\section{Other matters}

In achieving the purpose of this Act, all persons exercising functions and powers under it, in relation to managing the use, development, and protection of natural and physical resources, shall have particular regard to-

\section{(a) kaitiakitanga:}

(aa) the ethic of stewardship:

(b) the efficient use and development of natural and physical resources:

(ba) the efficiency of the end use of energy:

(c) the maintenance and enhancement of amenity values:

(d) intrinsic values of ecosystems:

(e) [Repealed]

(f) maintenance and enhancement of the quality of the environment:

(g) any finite characteristics of natural and physical resources:

(h) the protection of the habitat of trout and salmon:

(i) the effects of climate change:

(j) the benefits to be derived from the use and development of renewable energy.

\section{Treaty of Waitangi}

In achieving the purpose of this Act, all persons exercising functions and powers under it, in relation to managing the use, development, and protection of natural and physical resources, shall take into account the principles of the Treaty of Waitangi (Te Tiriti o Waitangi).

While sustainable management is crucial to the RMA, it is a difficult concept. It was adapted from the international environmental law doctrine of sustainable development. ${ }^{19}$ Incorporating this into domestic legislation was a "drafter's nightmare" because the abstract

\footnotetext{
${ }_{19}$ John Hassan and Louise Cooney "Review of sections 6 and 7: principles, processes and confidence in decision-makers" (2012) 9 BRMB 167 at 167.
} 
principle needed to be given meaningful legal expression. ${ }^{20}$ The policy-makers had to formulate a section that would enable decision-makers to take into account the spectrum of values that can apply in decisions of resource allocation. ${ }^{21}$ The difficulties were not resolved after the section was drafted, but continued into its interpretation and application. Because of the broad, value-laden nature of s 5, its application is often difficult and uncertain. ${ }^{22}$ Thus the section is often a point of contention. ${ }^{23}$

Successive governments have failed to address the uncertainties, with the plethora of RMA amendments avoiding s $5 .{ }^{24}$ Somerville opined that this neglect was due to governments' aversion to the political ramifications that could result from making the necessary value judgments, which would likely involve curtailing development. ${ }^{25}$ The uncertainty has been exacerbated by the failure to provide direction via NPSs. ${ }^{26}$ Consequently, the responsibility has fallen to the courts to grapple with its application. ${ }^{27}$ However, they have not provided much assistance to interpreting s 5, making decision-makers' jobs difficult. ${ }^{28}$

In interpreting s 5, two different approaches have been developed. The drafters of the sections intended s 5 to be applied using the "environmental bottom line approach". ${ }^{29}$ This meant that s 5(2)(a) (b) and (c) constituted a non-negotiable bottom line and could not be "traded off". ${ }^{30}$ The courts originally followed this approach, ${ }^{31}$ applying the subsections as

${ }^{20}$ SD Upton "The Stace Hammond Grace Lecture: Purpose and Principle in the Resource Management Act" (1995) 3 Wai L Rev 17 at 20.

${ }^{21}$ Peter Skelton and Ali Memon "Adopting Sustainability as an Overarching Environmental Policy: a Review of section 5 of the RMA" (2002) 1 RMJ 1 at 2.

${ }^{22}$ King Salmon (SC), above n 1, at [150].

${ }^{23}$ IH Williams "The Resource Management Act 1991: Well Meant But Hardly Done" (1997-2000) 9 Otago L Rev 673 at 678 .

${ }^{24}$ For a list of the legislation see Ministry for the Environment Past RMA amendments (11 December 2013) $<$ www.mfe.govt.nz>.

${ }^{25}$ Royden Somerville, above n 12, at [IN6.03].

${ }^{26}$ Bret Birdsong, above $\mathrm{n} 7$, at 25 .

${ }^{27}$ Peter Skelton and Ali Memon, above n 21, at 4.

${ }^{28} \mathrm{IH}$ Williams, above $\mathrm{n} 23$, at 681.

${ }^{29}$ SD Upton, above n 20, at 40.

${ }^{30}$ SD Upton, above n 20, at 40.

${ }^{31}$ See Campbell v Southland District Council PT Wellington W114/94, 14 December 1994, 
"cumulative safeguards", that all had to be fulfilled before the purpose of the Act was met. ${ }^{32}$ However, this method of applying s 5 was superseded by the current "overall judgment approach". ${ }^{33}$ Rather than assessing whether a decision met the individual provisions of s 5, the courts used the matters within Part 2 to make an overall broad judgment of whether a decision promoted sustainable management. ${ }^{34}$ The broad and general nature of the section was one of the drivers of the change. The Environment Court said that the "deliberate openness" about the language of s 5 meant it was inappropriate to apply the section strictly. ${ }^{35}$ The courts also reasoned that the overall broad judgment approach recognised that the RMA has a single purpose, and that the approach provided for recognition of the benefits of a proposal and a weighing of conflicting considerations. ${ }^{36}$

While an in-depth analysis of the merits of the two approaches to applying s 5 is beyond the scope of this paper, it is relevant to note the courts' development of the approaches. The choice between the two methods is not clear-cut, ${ }^{37}$ yet the courts have not engaged in a detailed analysis to determine the most suitable approach. For example, New Zealand Rail Ltd v Marlborough District Council is cited as the genesis of the overall broad judgment approach and contains an oft-referenced articulation of it. ${ }^{38}$ However the main issue in the

Shell Oil New Zealand Ltd v Auckland City Council PT Auckland W8/94, 2 February 1994 and Plastic and Leathergoods Co Ltd v Levin School Board of Trustees PT Wellington W26/94, 19 April 1994.

32 Foxley Engineering Ltd v Wellington City Council PT Wellington W12/94, 16 March 1994 at 40 and Shell Oil New Zealand Ltd v Auckland City Council PT Auckland W8/94, 2 February 1994 at 10.

${ }^{33}$ See Aquamarine Ltd v Southland Regional Council NZEnvC Christchurch C126/97, 15 December 1997, New Zealand Rail Ltd v Marlborough District Council [1994] NZRMA 70 (HC), Trio Holdings v Marlborough District Council [1997] NZRMA 97 (PT), North Shore City Council v Auckland Regional Council (1996) 2 ELRNZ 305 (NZEnvC) and Mainpower NZ Ltd v Hurunui District Council [2011] NZEnvC 384.

${ }^{34}$ North Shore City Council v Auckland Regional Council (1996) 2 ELRNZ 305 (NZEnvC) and Peter Salmon, above n 18, at [RM5.01].

${ }^{35}$ New Zealand Rail Ltd v Marlborough District Council, above n 33, at 86.

${ }^{36}$ Mainpower NZ Ltd v Hurunui District Council, above n 33, at [53] and North Shore City Council v Auckland Regional Council above n 33, at 45.

${ }^{37}$ See Simon Upton, Helen Atkins and Gerard Willis "Section 5 re-visited: a critique of Skelton \& Memon's analysis" (2002) 3 RMJ 10 at 18 and Sian Elias, Chief Justice of New Zealand "Righting Environmental Justice" (address to the Resource Management Law Association, Auckland, 25 July 2013) at 12.

${ }^{38}$ New Zealand Rail Ltd v Marlborough District Council, above n 33, at 19 referred to in King Salmon (SC), above n 1, at [39] and North Shore City Council v Auckland Regional Council above n 33, at 45. 
case was the application of $\mathrm{s} 6(\mathrm{a})$, not s $5 .{ }^{39}$ As a result, the use of New Zealand Rail as authority for the overall broad judgment approach has been criticised. ${ }^{40}$ Later cases, most of them in the Environment Court, use New Zealand Rail as authority and apply s 5 using the overall broad judgment approach without much analysis of its merits. ${ }^{41}$ Some commentators have said that an assessment of the best method for applying s 5 should be conducted, preferably by an appellate court. ${ }^{42}$ An alternative solution to the uncertainties within s 5 is for Parliament to clarify its intention. Arguably it is more appropriate in the case of the value-laden s 5 that elected policy-makers make the judgments, rather than the unelected judiciary.

\section{Reforms}

Recently the National Government has announced several plans to reform the RMA. The reforms are intended to increase national guidance, improve certainty and reduce litigation, among other goals. ${ }^{43}$ While some may have hoped for assistance with s 5 , the Technical Advisory Group appointed to assess potential changes was precluded from addressing $\mathrm{s}$ $5 .{ }^{44}$ However, the proposed changes do include reform to other sections in Part 2, specifically ss 6 and 7. The matters within the two sections will be amalgamated into one s $6 .{ }^{45}$ Some of the matters will be deleted and others added, to "rebalance" the sections away from what is seen as an overly ecocentric list of matters. It is also intended to reword the start of s 6 by replacing "in achieving the purpose of the Act" with "in making an overall broad judgment under section $5 " .{ }^{46}$

\footnotetext{
${ }^{39}$ New Zealand Rail Ltd v Marlborough District Council, above $\mathrm{n} 33$.

${ }^{40}$ Simon Upton, Helen Atkins and Gerard Willis, above n 21, at 18.

${ }^{41}$ See Aquamarine Ltd v Southland Regional Council, Trio Holdings v Marlborough District Council and North Shore City Council v Auckland Regional Council, above n 33.

${ }^{42}$ Sian Elias, above n 37, at 12 and Simon Upton, Helen Atkins and Gerard Willis, above n 37, at 20.

${ }^{43}$ Ministry for the Environment Improving Our Resource Management System: A discussion document (ME1103, Wellington, 2013) at $6-7$.

${ }^{44}$ Technical Advisory Group Report of the Minister for the Environment's Resource Management Act 1991 Principles (February 2012) at 15.

${ }^{45}$ Ministry for the Environment Resource Management Summary of Reform Proposals 2013 (2013, ME $1119)$ at 11.

${ }^{46}$ Ministry for the Environment, above n 45, at 13.
} 
The proposed reforms have been subject to widespread criticism. ${ }^{47}$ The process of developing the reforms, their substance and the justifications for them have been questioned. ${ }^{48}$ Some of the issues identified by various parties are that the changes weaken environmental protection, ${ }^{49}$ that they will lead to more uncertainty and discretion in decisions $^{50}$ and that the justifications for the changes are weak and unsupported by evidence. $^{51}$

\section{King Salmon}

Into this complex system, the King Salmon decision was released. It comments on many aspects of the RMA framework and could have far-ranging implications for resource management law, at many levels of the framework.

\section{The Proposal}

In 2003 the Marlborough Sounds Regional Council implemented the Marlborough Sounds combined regional, district and coastal plan. ${ }^{52}$ It designated certain areas as outstanding natural areas and zoned certain areas to prohibit aquaculture. King Salmon is one of New Zealand's largest salmon producers, with several farms in the Marlborough Sounds. ${ }^{53}$ It planned to expand its operations to eight new sites. As they were areas where aquaculture was a prohibited activity under the Marlborough Sounds Plan, King Salmon applied for a

\footnotetext{
47 Geoffrey Palmer Protecting New Zealand's Environment: An analysis of the Government's Proposed Freshwater Management and Resource Management Act 1991 Reforms (September 2013), Letter from Environmental Non-Governmental Organisations to Amy Adams (Minister for the Environment) regarding the report of the RMA 1991 Principles TAG (3 September 2012), Environmental Defence Society Technical Advisory Group Review of Sections 6 and 7 of the Resource Management Act 1991 (April 2012) and Jan Wright, Parliamentary Commissioner for the Environment Improving out resource management system: a discussion document (Submission to the Minister for the Environment, 2 April 2013).

${ }^{48}$ Ministry for the Environment Summary of submissions: improving our resource management system (2013).

${ }^{49}$ Geoffrey Palmer, above n 47, at 4 and Jan Wright, above n 47, at 12.

${ }^{50}$ Sian Elias, above n 37, at 12.

${ }^{51}$ Geoffrey Palmer, above n 47, at [124].

${ }^{52}$ Marlborough District Council Marlborough Sounds Resource Management Plan (2003).

${ }^{53}$ Board of Inquiry, New Zealand King Salmon Requests for Plan Changes and Applications for Resource Consents, 22 February 2013 [King Salmon (Board)] at [30].
} 
plan change to rezone the particular areas, making salmon farming a discretionary activity and therefore permitted with a resource consent. ${ }^{54}$

The application was determined to be a matter of national importance by the Minster of Conservation and so a Board of Inquiry (the Board) was convened in order to decide it. The Board approved four of the eight sites applied for. The Environmental Defence Society (EDS) and Sustain Our Sounds, as submitters to the Board hearing, appealed the decision to the High Court. ${ }^{55}$ Dobson J upheld the Board's decision. ${ }^{56}$ EDS and Sustain Our Sounds appealed separately to the Supreme Court on one and three sites respectively. ${ }^{57}$ Sustain Our Sounds' appeal was dismissed, but in Environmental Defence Society v New Zealand King Salmon Co Ltd the Supreme Court overturned the Board's decision, rejecting King Salmon's application for the rezoning of the particular site.

\section{E The Supreme Court Decision}

In essence, the Supreme Court decision is a rejection of the way the Board applied the NZCPS. In considering the plan change, the Board was required to "give effect to" the NZCPS. ${ }^{58}$ In doing this, it followed the Environment Court's precedent, applying the s 5 overall broad judgment approach to the NZCPS. ${ }^{59}$ Therefore while the plan change did not meet two of the NZCPS policies, 13(1)(a) and 15(a), it gave effect to policy 8, and so the Board concluded that the change gave effect to the NZCPS. ${ }^{60}$ In rejecting the Board's approach, the Court held that:

\footnotetext{
${ }^{54}$ King Salmon (Board), above n 53, at [3].

${ }^{55}$ Under the Resource Management Act 1991, s102.

${ }^{56}$ Environmental Defence Society Inc \& Sustain Our Sounds Inc v The New Zealand King Salmon Co Ltd [2013] NZHC 1992, [2013] NZRMA 371.

${ }^{57}$ Sustain Our Sounds Inc v New Zealand King Salmon Co Ltd [2014] NZSC 40 and King Salmon (SC), above $\mathrm{n} 1$.

${ }^{58}$ Resource Management Act 1991 s 67(3).

${ }^{59}$ Man O'War Station Ltd v Auckland Council [2013] NZEnvC 233 and Te Runanga O Ngai Te Rangi Iwi Trust v Bay of Plenty Regional Council [2011] NZEnvC 402, cited in King Salmon (Board), above n 53, at [42].

${ }^{60}$ King Salmon (Board), above n 53, at [1243].
} 
a) The overall broad judgment approach was not appropriate for applying the NZCPS. The RMA framework and the NZCPS itself indicated that the NZCPS was intended to be capable of containing policies that were "environmental bottom lines" that bound decision-makers.

b) Policies 13(1)(a) and 15(a) of the NZCPS, which involved the protection of outstanding natural areas, were worded with sufficient precision and direction to constitute environmental bottom lines. ${ }^{61}$

c) When giving effect to the NZCPS, the Board was not entitled to refer back to s 5 of the Resource Management Act 1991 unless specific exceptions applied. ${ }^{62}$

The majority in King Salmon said that the overall broad judgment approach was not consistent with the NZCPS's place in the hierarchical and "carefully structured legislative scheme" of the RMA, nor with the clear intention of the scheme to be able to provide increasingly more specific direction to decision-makers. ${ }^{63}$ In contrast, it would be consistent with the hierarchy and with the directive of the elements to interpret the policies as environmental bottom lines and to bar decision-makers from referring to $\mathrm{s} 5$ when applying the NZCPS.

\section{$V$ The Implications of King Salmon}

Depending on the extent of the case's application, King Salmon has potential implications for NZCPS policies, National Policy Statements, s 5 and the proposed reforms.

\section{F Policies 13 and 15: Outstanding Natural Areas}

The most immediate result of King Salmon is its effect on policies 13(1)(a) and 15(a) of the NZCPS. These protect areas of outstanding natural character, features and landscapes:

\section{Preservation of natural character}

\footnotetext{
${ }^{61}$ King Salmon (SC) at [126]-[127].

${ }^{62}$ King Salmon (SC) at [85] and [88].

${ }^{63}$ King Salmon (SC) at [142].
} 
(1) To preserve the natural character of the coastal environment and to protect it from inappropriate subdivision, use, and development:

(a) avoid adverse effects of activities on natural character in areas of the coastal environment with outstanding natural character...

\section{Natural features and natural landscapes}

To protect the natural features and natural landscapes (including seascapes) of the coastal environment from inappropriate subdivision, use, and development:

(a) avoid adverse effects of activities on outstanding natural features and outstanding natural landscapes in the coastal environment...

King Salmon concluded that these policies were uncompromisable bottom lines because of the prescriptive phrasing. In particular, "avoid" is a strong direction meaning "prevent the occurrence of". ${ }^{64}$ As a result of this interpretation, councils must prohibit any activity that has an adverse effect on an outstanding area's natural qualities. This is a strict result and there was concern it would be overly prohibitive. In his dissenting judgment, William Young $\mathrm{J}$ argued that councils might have to restrict activities on private land or prohibit navigational aids. ${ }^{65}$ The Board in King Salmon was concerned that it would set an impossibly high threshold for activities. ${ }^{66}$ However, the majority in King Salmon thought that absurd results would be able to be avoided by taking a narrow interpretation of the meaning of 'effect' in the policies, which would preclude a restriction on temporary or minor adverse effects. Whether or not King Salmon causes undesirable restrictions on activities in areas of outstanding character will depend on how the case is applied in the particular situation, and whether the relevant provisions afford sufficient flexibility in the circumstances.

Beyond the practical effects, there are likely to be policy implications of a stricter protection of outstanding natural areas. Councils may be less willing to classify areas as outstanding for fear of the overly prohibitive result. Therefore stricter protection under

\footnotetext{
${ }^{64}$ King Salmon (SC) at [126].

${ }^{65}$ King Salmon (SC) at [201].

${ }^{66}$ King Salmon (Board) at [1181].
} 
King Salmon could be counterproductive for the safeguarding of outstanding areas if fewer areas are classified such in the future. It is also possible that the stricter standard, being more likely to restrict activities, will result in more parties challenging the classifications. Outstanding natural areas have already been the focus of much litigation, ${ }^{67}$ and, in the words of the Supreme Court, the process of designating such areas is already a thoroughgoing one. ${ }^{68}$ Challenges will only extend this undertaking, adding to the workload of councils. In addition, the case causes a significant inconsistency between the protection extended to outstanding natural coastal areas and inland outstanding areas, as inland areas are not protected by such a high standard in a national instrument. ${ }^{69}$ A potential solution to these issues is the promulgation of an NPS on outstanding natural areas. This has been called for by environmental non-governmental organisations, albeit not in response to King Salmon. ${ }^{70}$ They argue it would provide national consistency and reduce the burden on local authorities. Countering the potentially negative effects of King Salmon on the classification process supports such a proposition.

\section{G NZCPS Policies}

King Salmon means that in addition to policies 13 and 15, local authorities have no discretion over whether or not to implement other prescriptive, "bottom line" policies within the NZCPS. However, most of the policies in the NZCPS are phrased in a way that enables flexibility, using words like "recognise" and "encourage" for example. The Court provided an extensive list of policies that contain wording that gives decision-makers flexibility. ${ }^{71}$ In contrast, policy 23 (discharge of contaminants) and policy 29 of the NZCPS were identified by the Court as sufficiently specific and direct. ${ }^{72}$ Policy $23(2)$ (a) requires

\footnotetext{
${ }^{67}$ To the extent that a test has been developed for recognising such areas. See Wakatipu Environmental Society v Queenstown Lakes District Council [2000] NZRMA 59 (NZEnvC) and Pigeon Bay Aquaculture Ltd $v$ Canterbury Regional Council [1999] NZRMA 209 (NZEnvC).

${ }^{68}$ King Salmon (SC) at [73] and Marlborough District Council Marlborough Sounds Resource Management Plan (2003) at chpt 5 and app 1.

${ }^{69}$ Stephen Brown "What it means for coastal management" (speech to Environmental Defence Society's seminar on EDS v King Salmon, Auckland, 4 June 2014).

70 Letter from Environmental Non-Governmental Organisations to Amy Adams (Minister for the Environment) regarding the report of the RMA 1991 Principles TAG (3 September 2012) at [37].

${ }^{71}$ King Salmon (SC) at [127].

${ }^{72}$ King Salmon (SC) at [127].
} 
councils to not allow the discharge of human waste directly into water in the coastal environment. Policy 29 requires local authorities to amend documents in certain ways, and to give effect to the policy as soon as practicable. These are unlikely to be unnecessarily burdensome on local authorities and it is logical to impose them as binding bottom lines. Other policies may be sufficiently prescriptive, although not specifically referred to as such in King Salmon. For example, policy 11(a) (indigenous biological diversity) directs local authorities to avoid adverse effects on indigenous taxa, habitats and ecosystems. King Salmon then results in a stricter application of the NZCPS, as local authorities have less discretion in applying policies. However, because many policies contain considerable flexibility there remains scope for choice.

\section{H National Policy Statements}

The King Salmon decision may be generalised and applied to other instruments within the framework, such as other National Policy Statements. An assessment of whether the decision extends to an NPS involves first looking at whether the environmental bottom line approach applies - both to an NPS generally and to a particular policy within the NPS and second assessing whether a decision-maker should be precluded from referring to $\mathrm{s} 5$ when interpreting the NPS. The two elements are related but not contingent on each other.

1 Was the planning document intended to be capable of containing environmental bottom lines?

In deciding that it was appropriate to apply the environmental bottom line approach to the NZCPS, the Supreme Court considered the role that the instrument was intended to fulfil, noting its place in the hierarchy and its use as a tool to exercise Ministerial control. It also looked at the subjects of policies and considered that the overall broad judgment approach would be illogical if applied to such policies. Many of the factors used in King Salmon to support these findings in relation to the NZCPS are also applicable to NPSs.

The Supreme Court undertook a detailed analysis of certain RMA provisions in coming to its decision. These were used as evidence that the NZCPS was intended to be capable of 
containing prescriptive bottom lines, because they showed that the NZCPS played a significant role in the RMA hierarchy and that it was intended to be used by Ministers to direct local authorities. ${ }^{73}$ This part of the Court's reasoning is easily applied to NPSs: all of the RMA provisions in question apply dually to NPSs and an NZCPS, such as the long and comprehensive promulgation process ${ }^{74}$ mechanisms for monitoring local authorities' compliance $^{75}$ and the strong obligation "to give effect to" the instruments. ${ }^{76}$

The Court also relied on provisions of the RMA that detailed the potential contents of the NZCPS, and actual policies within the NZCPS. ${ }^{77}$ It thought that some of the topics that the NZCPS was statutorily permitted to contain, and some of the actual policies in the NZCPS would be undermined if they were not applied as binding standards. Section 58 contains an extensive list of matters that an NZCPS may contain. For example, s 58(a) sets out the Minister's ability to set national priorities for preserving the natural character of the coastal environment. The Court thought that it was "inconceivable" that regional councils could treat such priorities as nothing more than relevant considerations, and potentially act inconsistently with them. ${ }^{78}$ Particular policies within the NZCPS were used by the Supreme Court to support this argument. Policy 29, for example, would make little sense if applied with the overall broad judgment approach, as then councils could decide not to adhere to the timeframe. ${ }^{79}$

The RMA does not provide an equivalent contents provision such as s 58 for NPSs. However, s 58A was relied upon in the Supreme Court's 'practicality' argument, and this does apply to any NPS. ${ }^{80}$ Furthermore, several policies within various NPSs are analogous to policy 29. For example, as advanced in a recent Board of Inquiry hearing on the Tukituki Catchment Proposal, the NPSFM contains policies such as the "limits-based framework"

\footnotetext{
${ }^{73}$ King Salmon (SC) at [75], [76] and [78].

74 Resource Management Act 1991, s 32 and ss 47-52.

75 Resource Management Act 1991, ss 28 and 293.

${ }^{76}$ Resource Management Act 1991, s 67(3).

${ }^{77}$ King Salmon (SC) at [117]-[124].

${ }^{78}$ King Salmon (SC) at [118].

${ }^{79}$ King Salmon (SC) [122].

${ }^{80}$ King Salmon (SC) at [123].
} 
for quality levels, which logically ought to be applied as non-discretionary rules. ${ }^{81}$ In the National Policy Statement for Renewable Energy Generation, Policy H contains specific timeframes. ${ }^{82}$ Therefore there are sections of the RMA and policies within the NPSs on which to rest the argument that an NPS was intended to be used by the Minister to create binding policies.

Finally, the Supreme Court's general endorsement of the bottom line approach in applying an NZCPS supports an application of the same approach for NPSs. The Court found that the approach is not inconsistent with the purpose of the RMA, that the RMA definition of 'policy' does not exclude the policies from being prescriptive 'rules' in the ordinary sense of the word, and that applying policies as bottom lines would not be impractical. ${ }^{83}$ The general criticisms of the overall broad judgment approach are relevant for applying the decision to an NPS. King Salmon said the overall broad judgment approach created uncertainty and inconsistent results. ${ }^{84}$ The Court was concerned that an overall broad judgment approach applied to the NZCPS would result in decision-makers identifying conflicts between policies too readily, preferring one over the other without a "thoroughgoing attempt to find a way to reconcile them", and that the approach would destroy the subtleties in the phrasing of the different polices. ${ }^{85}$

Thus there is a compelling case for applying King Salmon to NPSs. However, the Supreme Court said that it was open for the Minister to say that the NZCPS was simply a list of relevant factors that councils could "give such weight as they think necessary". ${ }^{86}$ If the Minister made such a direction, the environmental bottom line approach may be inappropriate. A statement indicating this intention would nullify the implications drawn from the RMA framework that were material in King Salmon. A potential example of this

\footnotetext{
${ }^{81}$ Environmental Defence Society Comments on the Supreme Court Decision and the Draft Report and Decision (Submission to the Board of Inquiry on the Tukituki Catchment Proposal, 16 May 2014) at [4].

${ }^{82}$ Ministry for the Environment National Policy Statement for Renewable Energy Generation 2011 (issued by notice in the New Zealand Gazette on 14 April 2011).

${ }^{83}$ King Salmon (SC) at [132].

${ }^{84}$ King Salmon (SC) at [137].

${ }^{85}$ King Salmon (SC) at [127] and [131].

${ }^{86}$ King Salmon (SC) at [143].
} 
is the NPSET preamble, which states that the NPS is "intended to guide decision-makers" and "to be a relevant consideration". ${ }^{87}$ However, this is not a clear refutation of the environmental bottom line approach, so it seems unlikely it would be sufficient to displace the other factors that indicate King Salmon's reasoning is applicable.

\section{Do the planning document's policies amount to bottom lines?}

The next crucial question in applying King Salmon's environmental bottom line approach is whether a particular policy has sufficiently direct and prescriptive language to require it to be applied as a bottom line. The Court said that some policies are "stated in such directive terms that the decision-maker has no option but to implement [them]". ${ }^{88}$ Many of the policies in NPSs are flexible, and therefore would not be applied as binding rules. There are some that are directive, however. The NPSFM for example has policies regarding overallocation of water that could support a bottom line interpretation. ${ }^{89}$ The NPSET has several policies that could be applied as bottom lines, including policy 8 which is very similar to the NZCPS, with a requirement to "avoid adverse effects on outstanding natural areas". 90 However, the NPSREG contains policies that are not strongly worded. ${ }^{91}$

The environmental bottom line approach rests, naturally, on the existence of a bottom line to uphold. Therefore even if the approach can apply generally to a particular NPS, a decision-maker will not be bound if the policy relevant in the particular case contains flexible language. As a result the application of King Salmon rests on the wording of the particular policy. This element of the decision may restrict the scope of the application of environmental bottom lines: if few policies are directive in nature the approach will not apply widely.

\footnotetext{
${ }^{87}$ Ministry for the Environment National Policy Statement on Electricity Transmission (issued by notice in the New Zealand Gazette on 13 March 2008), Preamble.

${ }^{88}$ King Salmon (SC) at [129].

${ }^{89}$ Ministry for the Environment National Policy Statement on Freshwater Management 2011 (issued by notice in the New Zealand Gazette on 12 May 2011), Policies A1(b) and B2.

${ }^{90}$ Ministry for the Environment National Policy Statement on Electricity Transmission (issued by notice in the New Zealand Gazette on 13 March 2008).

${ }^{91}$ Ministry for the Environment National Policy Statement for Renewable Energy Generation 2011 (issued by notice in the New Zealand Gazette on 14 April 2011).
} 


\section{Is the decision-maker entitled to refer back to the purpose of the RMA?}

The other facet of King Salmon that may have implications for decision-makers in applying NPSs is the direction that the Board was not entitled to refer back to Part 2 in applying the NZCPS. The Board's approach was that "part II is not just the starting point but also the finishing point to be considered in the overall exercise of discretion". ${ }^{92}$ King Salmon held this was incorrect, for several reasons. First, the Court said that the long process of creating the NZCPS made it "implausible that the ultimate determinant of an application such as the present would be pt 2 and not the NZCPS". ${ }^{93}$ Second is the hierarchical nature of the RMA scheme which provides for the Minister to direct council decisions. The Court reasoned that this would be undermined by allowing decision-makers to refer back to Part 2, creating the risk that decision-makers would interpret Part 2 as "trumping" the NZCPS. ${ }^{94}$ The last factor was the NZCPS's role in the RMA hierarchy, translating the general principles in Part 2 to specific policies. Referring back to Part 2 would not be necessary nor helpful when there is a carefully expressed document fulfilling such a role. ${ }^{95}$ Broadly, these elements seem to apply to an NPS: the process is the same and they fulfil a similar role in the hierarchy by providing a mechanism for Ministerial direction and a specific formulation of the general principles.

However, it is possible to argue that the National Policy Statements are materially different from the NZCPS, making it appropriate to refer back to $\mathrm{s}$ 5. NPSs fulfil a slightly different role in the framework in that they are not a single specialised planning document as the NZCPS is. As such they are much broader in scope than the NZCPS. That is, they may be used for a variety of situations, with little restrictions on topics beyond a requirement that the NPS relates to a matter of national significance. ${ }^{96}$ As a less specialised instrument, therefore, it could be argued that the King Salmon requirement to not go beyond the NZCPS

\footnotetext{
${ }^{92}$ King Salmon (Board) at [1227].

${ }^{93}$ King Salmon (SC) at [86].

${ }^{94}$ King Salmon (SC) at [86(b)].

${ }^{95}$ King Salmon (SC) at [90].

${ }^{96}$ Derek Nolan, above n 6, at [3.75] and Resource Management Act 1991, s 45.
} 
to Part 2 is inappropriate, because an NPS was not intended to be the sole instrument for decision-makers. Fonterra and DairyNZ noted in their submission before the Board of Inquiry on the Tukituki plan change proposal that the RMA provides a different purpose for an NZCPS than for an NPS. ${ }^{97}$ The purpose of an NZCPS is to state policies "to achieve the purpose of this Act" while the purpose of an NPS is to state policies that "are relevant to achieving the purpose of this Act". ${ }^{98}$ Thus it can be argued that the NPSFM was not intended to be an "all encompassing document" as the NZCPS was, and therefore it is appropriate to consider other relevant matters, such as Part 2, when applying the NPSFM.

In coming to its conclusion, much of the focus of King Salmon was on assessing how the NZCPS was intended to be applied, and it relied largely on the RMA framework rather than the contents of the NZCPS. Consequently, it is unclear what the result would be if an NPS contained a contrary expectation. The NPSET for example contains a statement in its Preamble that seems to contradict King Salmon: "the [NPSET] is not meant to be a substitute for, or prevail over, the Act's statutory purpose or the statutory tests already in existence ... [it] is subject to Part 2 of the Act. ... intended to be a relevant consideration...".99 In its preamble, the NPSFM says it is a "first step", which suggests that the NPSFM was not intended to be the sole decision-making instrument. ${ }^{100}$

The Board of Inquiry for the Tukituki proposal did not engage in a discussion of whether King Salmon ought to apply to the NPSFM, presumably because the result of the draft decision, which was released before King Salmon, would not change if King Salmon applied. ${ }^{101}$ Nevertheless, the Board of Inquiry did seem to consider itself bound by the restriction to not refer back to Part 2, making changes to the wording of the decision. ${ }^{102}$ In

\footnotetext{
${ }^{97}$ Fonterra and DairyNZ Comments on Draft Decision and Report and Comments on King Salmon Decision (Submission to the Board of Inquiry on the Tukituki Catchment Proposal, 14 May 2014) at 6.

${ }^{98}$ Resource Management Act 1991, ss 45 and 56.

${ }^{99}$ Ministry for the Environment National Policy Statement on Electricity Transmission (issued by notice in the New Zealand Gazette on 13 March 2008) Preamble.

${ }^{100}$ Ministry for the Environment National Policy Statement on Freshwater Management 2011 (issued by notice in the New Zealand Gazette on 12 May 2011) Preamble.

${ }^{101}$ Board of Inquiry Tukituki Catchment Proposal Draft Report and Decision (April 2014).

102 Board of Inquiry Tukituki Catchment Proposal Final Report and Decisions (18 June 2014) at [151].
} 
future cases, where the application of King Salmon would alter the result, the question will likely be analysed more thoroughly. There may be scope to argue that the preambular statements are clear enough to show a contrary intention and, as a result, the King Salmon restriction on reference to 5 should not be applied.

\section{The future of National Policy Statements}

King Salmon might have an impact on the development of future National Policy Statements. The decision provides central government with the potential for a strong instrument to direct local councils. However, the government could elect to utilise this influence or not, and the evidence suggests that the current government is unlikely to. Little priority has been given to rectifying the problem with the dearth of NPSs in operation. The government has instead relied on other, more easily implemented instruments to execute its policies, such as legislation, regulations, National Environment Standards and ad hoc guidance. ${ }^{103}$ It may be that the lengthy and involved process of promulgating NPSs, generally longer than a three-year government term, is part of what makes it more attractive for governments to use other modes. ${ }^{104}$ If this trend is continued, the effect of King Salmon will be curtailed, as the decision could only apply in cases when there is a relevant NPS.

\section{Implications for the purpose of the RMA}

As mentioned above, s 5 of the RMA provides for and defines the purpose of the Act. In King Salmon, while the Court was not required to engage in a prolonged analysis of the application of the section, there are elements of the case that will influence the future of the purpose of the RMA and its application. The decision will have an impact through the endorsement of the environmental bottom line approach, a shift in the role of s 5 , and the Supreme Court's direction on the interpretation of sustainable management.

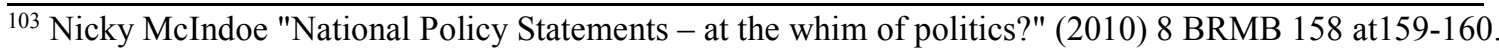
${ }^{104}$ Nicky McIndoe, above n 103, at 159.
} 


\section{Environmental Bottom Line Approach}

Section 5 is typically applied using the overall broad judgment approach, ${ }^{105}$ and King Salmon does not overturn the precedents that establish this rule. However, the Supreme Court's favouring of the environmental bottom line approach when applying the NZCPS is relevant for a critical assessment of the courts' approach to applying s 5, particularly in light of the uncertainty and lack of analysis surrounding the two options.

A major issue the Supreme Court considered was the uncertainty created by the overall broad judgment approach. Uncertainty leads to inconsistent treatment and makes the task of local authorities more difficult. The Court said the overall broad judgment approach resulted in a "complex and protracted decision-making process" and noted previous decisions made in the Marlborough Sounds with inconsistent outcomes. ${ }^{106}$ This concern has been raised with respect to the overall broad judgment and s 5. Williams said the approach renders the purpose of the Act "virtually meaningless" and that s 5 may as well say that sustainable management means "sugar and spice and all things nice". ${ }^{107}$ Rt Hon Dame Sian Elias said that the approach should be critically assessed because an approach with such a wide balancing of values is not usually favoured by courts. ${ }^{108}$ This criticism is underscored by the issues with the RMA generally: local governments have called for more direction, ${ }^{109}$ and more national guidance is a goal of the reforms. ${ }^{110}$

An issue with the environmental bottom line approach that was raised, both in King Salmon and when applying the approach to $\mathrm{s} 5$, is the concern that the approach will be unworkable, because the result would be too strict or because there would be conflict between the subsections. The cases that developed the overall broad judgment approach were concerned

\footnotetext{
${ }^{105}$ Royden Somerville, above n 12, at [IN4.03].

${ }^{106}$ King Salmon (SC) at [137] - [138].

${ }^{107} \mathrm{IH}$ Williams, above n 23, at 682.

108 Sian Elias, above n 37, at 12.

${ }^{109}$ Ministry for the Environment, above n 48, at 11.

${ }^{110}$ Ministry for the Environment, above n 43, at 6- 7 .
} 
with being able to take into account and weigh the different elements. ${ }^{111}$ Fuller thought the environmental bottom line approach would cause most human activity to be restricted. ${ }^{112}$ However, Upton says that there is enough flexibility within s 5 to enable the approach to be feasible in practice. ${ }^{113}$ Supporting this argument, the cases that applied the environmental bottom line approach did not seem to have this problem when applying the stricter approach. ${ }^{114}$

King Salmon considered that the possibility of conflict between policies and prohibitive results were not insurmountable barriers in applying the environmental bottom line approach. While the decision was specific to the NZCPS, some of the Supreme Court's analysis is general enough to be relevant to s 5. In line with Upton's argument, the Court thought the flexibility within the wording of the policies of the NZCPS prevented both an overly restrictive result and conflict between policies. ${ }^{115}$ However, the Court also said that in some cases policies may conflict, in which case reference can be made to s 5 to resolve it. ${ }^{116}$ Section 5 lacks this higher standard to resolve conflicts with. Therefore while the Court's willingness to use the environmental bottom line approach for the NZCPS supports an argument that the practicality issues can be overcome for s 5, not all of the reasoning applies to 5 .

\section{The implications for interpreting the meaning of $s 5$}

King Salmon provides authority on other aspects of s 5. First, the meaning of 'while' in the section has been debated as a corresponding but separate question to the issue of which two

\footnotetext{
${ }_{111}$ Mainpower NZ Ltd v Hurunui District Council, above n 33, at [53], North Shore City Council v Auckland Regional Council, above n 33, at 45-46, Trio Holdings v Marlborough District Counil, above n 33, at 36, and New Zealand Rail Ltd v Marlborough District Council, above n 33, at 19.

112 Peter Fuller "The Resource Management Act 1991: “An Overall Broad Judgment'” (2003) 7 NZ J Envtl L 243 at 243.

113 Simon Upton, Helen Atkins and Gerard Willis, above n 37, at 19.

${ }^{114}$ Plastic and Leathergoods Co Ltd v Levin School Board of Trustees, above n 31, McIntyre v Christchurch City Council (1996) 2 ELRNZ 84 (PT), Shell Oil New Zealand Ltd v Auckland City Council, above n 31, Foxley Engineering Ltd v Wellington City Council, above n 32 and Campbell v Southland District Council., above $n 31$.

${ }^{115}$ King Salmon (SC) at [129].

${ }^{116}$ King Salmon (SC) at [130].
} 
approaches should be used. The issue is that the 'while' in s 5 is ambiguous: it could be either a subordinating or a coordinating conjunction. ${ }^{117}$ That is, the initial aspects set out in s 5 could be balanced against the subparagraphs, or the subparagraphs could be necessary preconditions. Whether this has much effect on results is doubtful: Somerville said the courts have not considered the question to be a key determinant in deciding how to apply s $5 .{ }^{118}$ Nevertheless, general consensus seems to be that 'while' means that the two elements of s 5 could be balanced against each other. ${ }^{119}$ The Supreme Court has confirmed this, saying that while means "at the same time as". ${ }^{120} \mathrm{~A}$ final and authoritative decision on this issue is useful for clarifying the interpretation of $\mathrm{s} 5$.

The Supreme Court provides further instruction to interpretation by emphasising the protective nature of $\mathrm{s} 5$. It repeatedly said that environmental protection is a "core element of sustainable management". ${ }^{121}$ The Court used this element of the definition to support its reasoning that applying the environmental bottom line approach to the NZCPS was consistent with the purpose of the RMA. ${ }^{122}$ Such a finding from the Supreme Court is useful to elucidate s 5, and in arguing for environmental bottom lines, and more generally for environmental protection under the Act.

\section{King Salmon and the role of $s$}

One of the main results of the case is to prevent a decision-maker from referring to $\mathrm{s} 5$ in making a decision under the NZCPS. The extent of the application of this aspect of the case may be narrow or broad. Nevertheless, the restriction has a direct effect on the role of s 5 in the RMA framework: it will now have less influence on decision-makers' everyday operations. This element of the decision accords with what commentators have said on the

${ }^{117}$ Derek Nolan, above n 6, at [3.24].

118 Royden Somerville, above n 12, at [IN4.03(1)].

${ }^{119}$ Simon Upton, Helen Atkins and Gerard Willis, above n 37, at 13 and Derek Nolan, above n 6, at [3.24].

${ }^{120}$ King Salmon (SC) at [24(C)].

${ }^{121}$ King Salmon (SC) at [24(d)].

${ }^{122}$ See King Salmon (SC) at [132] and [148]. 
issue. ${ }^{123}$ King Salmon agreed that the section was not intended to be an operative provision for planning decisions to be made under. ${ }^{124}$

The effect of this change, conditional on a wide application of King Salmon, may be that the overall broad judgment approach is used much less, as decision-makers have fewer situations where they are required to engage with s 5 . Instead they will be able to rely on the policy documents that sit under s 5 that are "translating the general to the specific". If more NPSs are developed, a two-tiered framework with a combination of the two approaches may result, where lower practical documents are applied with a strict environmental bottom line approach, and the more general overall broad judgment approach being reserved for the higher-level, abstract provisions.

\section{J Implications for Reforms}

\section{Overall Broad Judgement}

As outlined previously, the Government has proposed several reforms to the RMA, which have been criticised heavily. The overall broad judgment approach is an integral part of the rationale behind the reforms to Part 2. First, the Technical Advisory Group's (TAG) report on the principles of the RMA said that it is more appropriate to have a large list of considerations, as in the proposed s 6 , when making an overall broad judgment. ${ }^{125}$ Second, they justify additions to the list of considerations in ss 6 and 7 using the overall broad judgment approach. According to the TAG it is more appropriate to 'update' the list of relevant considerations under the overall judgment approach, and in particular to add nonenvironmental considerations. ${ }^{126}$ Finally, the addition of the overall broad judgment approach to s 6 is said to bring the section in line with case law. ${ }^{127}$

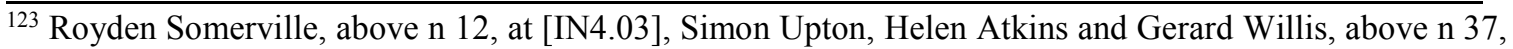
at 15 and Bret Birdsong, above $\mathrm{n} 7$, at 28.

${ }^{124}$ King Salmon (SC) at [151].

125 Technical Advisory Group, above n 44, at 19.

126 Technical Advisory Group, above n 44, at 19.

127 Technical Advisory Group, above n 44, at 68.
} 
In weakening the overall broad judgment approach, King Salmon can be used to criticise the three elements of the reforms that rely on the approach for justification. Opponents of the reforms have taken advantage of opportunity provided by the case to further dispute the soundness of the proposed changes. ${ }^{128}$ Elana Geddis said King Salmon takes the RMA away from the direction the reforms propose to take, and if the Government seeks to modify this position, it will need to provide robust reasoning to respond to the heightened scrutiny that comes with altering a decision from New Zealand's highest court. ${ }^{\mathbf{1 2 9}}$

In particular, King Salmon supports an argument against the introduction of the overall broad judgment in s 6 . Bringing a section in line with case law is a poor rationale when there is a lack of analysis into whether the approach is correct or not. King Salmon indicates that the approach is not necessarily the most appropriate, which weakens the rationale for the reforms further. It is hollow reasoning to simply adopt the courts' position without assessing it, when it is not a universally accepted approach, and when the issue has not been fully considered by an appellate court. Making a change to the central part of such a significant Act should have more sophisticated policy analysis behind it.

\section{Providing an alternative solution}

One of the purposes of the reforms is to provide more governmental direction, curbing decision-maker discretion in doing so. ${ }^{130}$ Questions have been raised about the effectiveness of the changes in achieving this purpose. ${ }^{131}$ Whether the reforms are effective or not, King Salmon may render this aspect of the reforms redundant by providing a means for achieving this purpose. The planned reforms could be substituted for an extension of the application of King Salmon. Specifically, the Government could implement more NPSs with directive, prescriptive policies, ones that will be applied as environmental bottom lines. This would achieve the purpose of limiting decision-maker discretion.

\footnotetext{
${ }^{128}$ See Elana Geddis Implications for the government's RMA reform agenda Seminar to the Environmental Defence Society and Geoffrey Palmer Implications of King Salmon and Ruataniwha Dam Decisions (5 May 2014) at [8].

${ }^{129}$ Elana Geddis, above n 128.

${ }^{130}$ Office of the Minister of the Environment "Setting the direction for phase two of the resource management reforms" Cabinet paper at [10] and Technical Advisory Group, above n 44, at 34.

131 Sian Elias, above n 37, at 12.
} 
This alternative has several other advantages to recommend it. First, it responds to those who criticise the reforms for the lack of thorough process in considering the result of such a major change to Part 2 of the Act. In particular, there are concerns around the insufficient consultation $^{132}$ and absence of rigorous analysis. ${ }^{133}$ Environmental Non-Governmental Organisations said the RMA was enacted with multi-party support, and thus major changes should be based on a similarly broad base of support. ${ }^{134}$ Local government expressed concern for the vast body of case law interpreting the central elements of the RMA that could be made irrelevant by such major changes. ${ }^{135}$ Hassan and Cooney argued, prior to King Salmon, that NPSs are a more appropriate way to update the RMA framework than reforming the core of the Act. ${ }^{136}$

Second, implementing reform via NPSs would be a step towards addressing a major problem in the framework: the uncertainty in s 5. King Salmon restricts decision-makers to applying the operative instrument without reference to $\mathrm{s} 5$. Thus elected policy-makers are making the value judgments that are involved when applying the abstract principle of sustainable management. This is the appropriate forum for such decisions, rather than the unelected judiciary making law as litigation comes before them, or local authorities applying their own interpretation to individual decisions.

Consequently, King Salmon gives the government an alternative instrument for implementing reforms, and perhaps one more palatable to opponents of the changes. The current Government's ambivalence to NPSs is recognised earlier in this paper, but King Salmon could, and indeed probably should, instigate a reconsideration of that position.

\footnotetext{
${ }^{132}$ Environmental Non-Government Organisations, above n 70, at [4].

133 Geoffrey Palmer, above n 47, at [124].

${ }^{134}$ Environmental Non-Government Organisations, above n 70, at [55].

${ }^{135}$ Ministry for the Environment, above n 48, at [10].

136 John Hassan and Louise Cooney, above n 19, at 169.
} 


\section{Conclusion}

King Salmon has the potential to impact New Zealand's resource management law in a range of ways. Local councils are required to avoid adverse effects on coastal outstanding areas, and there is a stricter standard for giving effect to the NZCPS, which may apply to the few NPSs in operation. Section 5 will now play a less direct role in operative resource management decisions, and a discussion could be kindled about the best approach to use when applying s 5. Finally, King Salmon may influence the Government's future plans for the RMA by affecting the proposed reforms.

King Salmon is a positive development for resource management law in that it provides the opportunity for much-needed certainty and consistency in the framework. A more comprehensive system of NPSs could extend this, and answer the calls for more direction from central government. This would also reduce the role of $\mathrm{s} 5$ in operative decisions which would improve certainty for everyday decisions, and shift the burden of balancing the s 5 elements onto policy-makers.

King Salmon adds to the conversation between the government and the courts as they grapple with the difficult task of implementing the RMA, a job that is no easier twentythree years after the Act's conception. King Salmon is a valuable comment, coming from New Zealand's highest court and being applicable to many elements of the RMA framework. The Government may take advantage of the opportunity King Salmon provides, or the case could be a catalyst for a closer look at the coherency of policy development, and the direction that developments in the RMA should take in the future. 


\section{Bibliography}

\section{K Cases}

Aquamarine Ltd v Southland Regional Council NZEnvC Christchurch C126/97, 15 December 1997

Auckland City Council v John Woolley Trust [2008] NZRMA 260 (HC)

Campbell v Southland District Council PT Wellington W114/94, 14 December 1994

Environmental Defence Society Inc v New Zealand King Salmon Co Ltd [2014] NZSC 38

Environmental Defence Society Inc \& Sustain Our Sounds Inc v The New Zealand King Salmon Co Ltd [2013] NZHC 1992, [2013] NZRMA 371

Foxley Engineering Ltd v Wellington City Council PT Wellington W12/94, 16 March 1994 Mainpower NZ Ltd v Hurunui District Council [2011] NZEnvC 384

Man O'War Station Ltd v Auckland Council [2013] NZEnvC 233

McIntyre v Christchurch City Council (1996) 2 ELRNZ 84 (PT)

New Zealand Rail Ltd v Marlborough District Council [1994] NZRMA 70 (HC)

North Shore City Council v Auckland Regional Council (1996) 2 ELRNZ 305 (NZEnvC)

Pigeon Bay Aquaculture Ltd v Canterbury Regional Council [1999] NZRMA 209 (NZEnvC)

Plastic and Leathergoods Co Ltd v Levin School Board of Trustees PT Wellington W26/94, 19 April 1994

Shell Oil New Zealand Ltd v Auckland City Council PT Auckland W8/94, 2 February 1994 Sustain Our Sounds Inc v New Zealand King Salmon Co Ltd [2014] NZSC 40

Te Runanga O Ngai Te Rangi Iwi Trust v Bay of Plenty Regional Council [2011] NZEnvC 402

Trio Holdings v Marlborough District Council [1997] NZRMA 97 (PT)

Wakatipu Environmental Society v Queenstown Lakes District Council [2000] NZRMA 59 (NZEnvC)

\section{Legislation and Government Material}

Board of Inquiry New Zealand King Salmon Requests for Plan Changes and Applications for Resource Consents (22 February 2013)

Board of Inquiry Tukituki Catchment Proposal Draft Report and Decision (April 2014)

Board of Inquiry Tukituki Catchment Proposal Final Report and Decisions (18 June 2014) 
Department of Conservation New Zealand Coastal Policy Statement 2010 (issued by notice in the New Zealand Gazette on 4 November 2010 and taking effect on 3 December 2010)

Marlborough District Council Marlborough Sounds Resource Management Plan (2003)

Ministry for the Environment Improving Our Resource Management System: A discussion document (ME1103, Wellington, 2013)

Ministry for the Environment National Policy Statement on Electricity Transmission (issued by notice in the New Zealand Gazette on 13 March 2008)

Ministry for the Environment National Policy Statement on Freshwater Management 2011 (issued by notice in the New Zealand Gazette on 12 May 2011)

Ministry for the Environment National Policy Statement for Renewable Energy Generation 2011 (issued by notice in the New Zealand Gazette on 14 April 2011)

Ministry for the Environment "Past RMA amendments" (11 December 2013) Resource Management Act <www.mfe.govt.nz>

Ministry for the Environment Proposed National Policy Statement on Indigenous Biodiversity (January 2011)

Ministry for the Environment Resource Management: Summary of Reform Proposals 2013 (August 2013)

Ministry for the Environment "Setting the direction for phase two of the resource management reforms" Report to Cabinet Strategy Committee

Ministry for the Environment Summary of submissions: improving our resource Management system

Resource Management Act 1991

Technical Advisory Group Report of the Minister for the Environment's Resource Management Act 1991 Principles (February 2012)

\section{Texts}

Derek Nolan (ed) Environmental and Resource Management Law (LexisNexis, online looseleaf ed)

Neil J Ericksen and others Planning for Sustainability: New Zealand Under the RMA (The International Global Change Institute, Hamilton, 2003)

Peter Salmon Environmental Law-Resource Management Act 1991 (Thomson Reuters, online looseleaf ed)

Rob Harris (ed) Handbook of Environmental Law (Royal Forest and Bird Protection Society, Wellington, 2004) 
Royden Somerville The Resource Management Act 1991: An Introductory Review (Thomson Reuters, online ed, 2004)

\section{N Journal Articles}

IH Williams “The Resource Management Act 1991: Well Meant But Hardly Done” (19972000) 9 Otago L Rev 673

John Hassan and Louise Cooney "Review of sections 6 and 7: principles, processes and confidence in decision-makers" (2012) 9 BRMB 167

Nicky Mcindoe "National Policy Statements - at the whim of politics?" (2010) 8 BRMB 158

Peter Skelton and Ali Memon "Adopting Sustainability as an Overarching Environmental Policy: a Review of section 5 of the RMA" (2002) 1 RMJ 1

Peter Fuller "The Resource Management Act 1991: 'An Overall Broad Judgment'” (2003) 7 NZ J Envtl L 243

SD Upton "The Stace Hammond Grace Lecture: Purpose and Principle in the Resource Management Act" (1995) 3 Wai L Rev 17

Simon Upton, Helen Atkins and Gerard Willis "Section 5 re-visited: a critique of Skelton \& Memon's analysis" (2002) 3 RMJ 10

\section{O Speeches, Submissions and Other Material}

Bret Birdsong Adjudicating Sustainability: New Zealand's Environment Court and the Resource Management Act (Ian Axford Fellowship in Public Policy, 2008)

Fonterra and DairyNZ Comments on Draft Decision and Report and Comments on King Salmon Decision (Submission to the Board of Inquiry on the Tukituki Catchment Proposal, 14 May 2014)

Elana Geddis "Implications for the government's RMA reform agenda" (speech to Environmental Defence Society's seminar on EDS v King Salmon, Auckland, 4 June 2014)

Environmental Defence Society Comments on the Supreme Court Decision and the Draft Report and Decision (Submission to the Board of Inquiry on the Tukituki Catchment Proposal, 16 May 2014)

Environmental Defence Society Technical Advisory Group Review of Sections 6 and 7 of the Resource Management Act 1991 (April 2012)

Gary Taylor, Chairman of Environmental Defence Society "Introduction" (speech to Environmental Defence Society's seminar on EDS v King Salmon, Auckland, 4 June 2014)

Geoffrey Palmer Implications of King Salmon and Ruataniwha Dam Decisions (5 May 2014) 
Geoffrey Palmer Protecting New Zealand's Environment: An analysis of the Government's Proposed Freshwater Management and Resource Management Act 1991 Reforms (September 2013)

Jan Wright, Parliamentary Commissioner for the Environment Improving out resource management system: a discussion document (Submission to the Minister for the Environment, 2 April 2013)

Letter from Environmental Non-Governmental Organisations to Amy Adams (Minister for the Environment) regarding the report of the RMA 1991 Principles TAG (3 September 2012)

Sian Elias, Chief Justice of New Zealand "Righting Environmental Justice" (address to the Resource Management Law Association, Auckland, 25 July 2013)

Stephen Brown "What it means for coastal management" (speech to Environmental Defence Society's seminar on EDS v King Salmon, Auckland, 4 June 2014)

Word count

The text of this paper (excluding table of contents, footnotes, and bibliography) comprises approximately 7,300 words. 